\title{
The use of pyloric exclusion for treating duodenal trauma: case series
}

\author{
Division of Trauma Surgery, Department of Surgery, School of Medical \\ Sciences, Universidade Estadual de Campinas (Unicamp), Campinas, \\ São Paulo, Brazil
}

- Gustavo Pereira Fraga

- Guilherme Biazotto

- José Benedito Bortoto

- Nelson Adami Andreollo

- Mario Mantovani

INTRDDUCTION

Because of its retroperitoneal location, injuries to the duodenum are relatively uncommon, occurring in only 3 to $5 \%$ of all abdominal injuries. ${ }^{1-3}$ The majority of duodenal injuries are caused by penetrating trauma that requires immediate exploratory laparotomy. Blunt injuries are more difficult to treat, mainly because of the difficulty in making a timely diagnosis. ${ }^{3,4}$ The vast majority of duodenal injuries can be managed by simple repair. ${ }^{1-4}$ Repair of multiple or delayed injuries often presents a technical challenge, and a variety of techniques have been described. The use of duodenal diversion through gastrojejunostomy was originally conceived in the early $1900 s,{ }^{5}$ but the simplified technique of pyloric exclusion was devised by Jordan and first reported by Vaughan et al. ${ }^{6}$ in 1977. This procedure consists of primary repair of the duodenal wound, closure of the pylorus through gastrotomy and gastrojejunostomy at the site of the gastrostomy.

Pyloric exclusion has been recommended in selected patients with complicated duodenal injury because it decreases the morbidity associated with dehiscence and fistula formation. However, the current philosophy for the management of pancreaticoduodenal injuries is that less treatment is probably the best treatment. ${ }^{7}$

口BJECTIVE

The purpose of this study was to report on a series of eight cases of duodenal repairs using pyloric exclusion and to describe reported complications or improvements in clinical outcomes among patients with complex duodenal trauma.

METHODS

The study design was cross-sectional followed by a report on eight cases of duodenal repairs using pyloric exclusion. A total of 93 patients with penetrating or blunt abdominal trauma and duodenal injury were admitted to the Division of Trauma Surgery of Universidade Estadual de Campinas (Unicamp), a large teaching hospital in a metropolitan area of 2.4 million people, between January 1990 and June 2007. All of the known cases of duodenal trauma among these patients were reviewed. The data were entered into a protocol and analyzed using the Epi-Info 6.04 computer software. Institutional ethics committee approval was obtained. The data collected included demographics, gender, age, mechanism of injury, admission vital signs, time elapsed between injury and operation, site and grade of duodenal injury, associated organ injuries, surgical procedure used, presence of complications (including duodenal fistula) and mortality. The trauma indices used included the Revised Trauma Score (RTS), ${ }^{8}$ Injury Severity Score (ISS) ${ }^{9}$ and Abdominal Trauma Index (ATI), ${ }^{10}$ and duodenal injuries were classified using the American Association for the Surgery of Trauma - Organ Injury Scale (AAST-OIS). ${ }^{11}$

For the operation, a midline incision was performed. The first priority was to control life-threatening hemorrhage from vascular structures or parenchymatous organs, followed by controlling the sources of gastrointestinal spillage. The duodenum was explored and mobilized by means of a Kocher maneuver, a Cattell-Braasch maneuver, or both. The injuries were graded and surgical repair was dictated by the surgeon's judgment. The decision to use pyloric exclusion was based on the degree of duodenal injury, extent of multiple organ involvement, degree of edema and friability of the duodenum, time elapsed between injury and treatment and the general condition of the patient.

Primary duodenal repair was attempted after debridement of the edges of the perforation in gunshot wounds (GSWs), and one-layer

\section{ABSTRACT}

CONTEXT AND OBJECTIVES: Significant controversy exists regarding the best surgical treatment for complex duodenal injuries. The aims of this study were to report on a series of eight cases of duodenal repairs using pyloric exclusion and to describe reported complications or improvements in clinical outcomes among patients with complex duodenal trauma.

DESIGN AND SETTING: Cross-sectional study followed by a case series in a university hospital.

METHODS: Data on eight patients with duodenal trauma who underwent pyloric exclusion over a 17.5 year period were collected and analyzed.

RESULTS: The causes of the injuries included penetrating gunshot wounds (GSW) in five patients and motor vehicle accidents (blunt trauma) in three patients. The time elapsed until surgery was longer in the blunt trauma group, while in one patient, the gunshot injury was initially missed and thus the procedure was carried out 36 hours after the original injury. The injuries were grade III $(50 \%)$ or IV $(50 \%)$ and the morbidity rate was $87.5 \%$. Four patients $(50 \%)$ died during the postoperative period from complications, including hypovolemic shock (one patient), sepsis (peritonitis following the missed injury) and pancreatitis with an anastomotic fistula (two patients).

CONCLUSIONS: Pyloric exclusion was associated with multiple complications and a high mortality rate. This surgical technique is indicated for rare cases of complex injury to the duodenum and the surgeon should be aware that treatment with a minimalistic approach, with only primary repair, may be ideal.

KEY WORDS: Duodenum. Wounds and injuries. Sutures. Morbidity. Pancreatitis. Gastroenterostomy. 


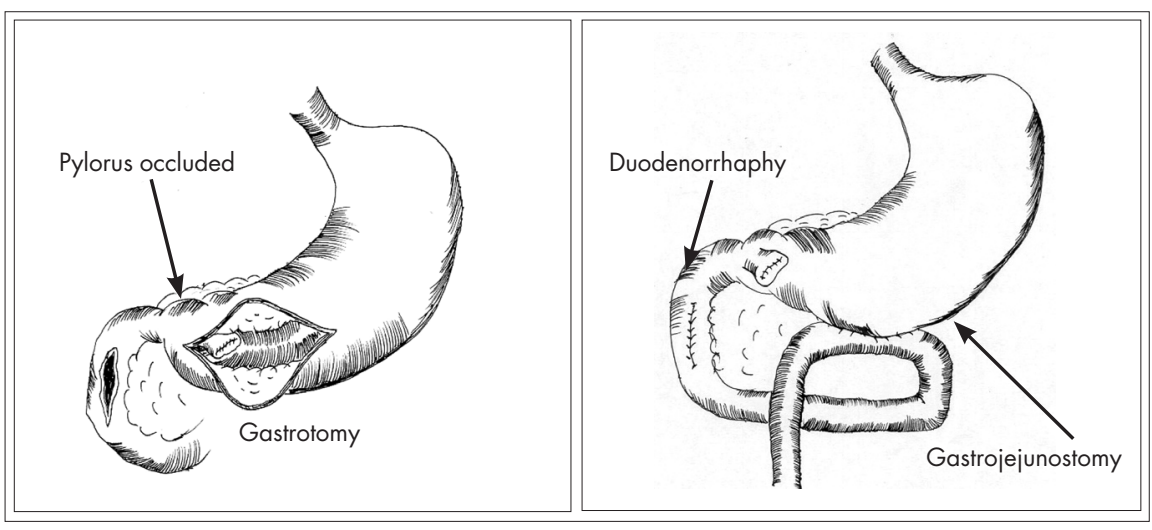

Figure 1. Pyloric exclusion procedure. ${ }^{12}$

Table 1. Summary of patients who underwent pyloric exclusion

\begin{tabular}{lccccll}
\hline Patient & Mechanism & RTS & $\begin{array}{c}\text { Time elapsed } \\
\text { between ad- } \\
\text { mission and } \\
\text { surgery }\end{array}$ & $\begin{array}{c}\text { Grade } \\
\text { of injury }\end{array}$ & $\begin{array}{l}\text { Associated abdominal } \\
\text { injuries }\end{array}$ & ATI \\
\hline 1 & Blunt & 7.84 & 18 hours & IV & Pancreas & 22 \\
2 & GSW & 7.84 & 40 minutes* & III & Colon, liver, pancreas & 47 \\
3 & GSW & 7.84 & 40 minutes & III & Colon, liver, stomach & 41 \\
4 & Blunt & 7.84 & 3 hours & IV & Pancreas & 21 \\
5 & GSW & 7.84 & 20 minutes & III & Liver & 20 \\
6 & GSW & 7.84 & 50 minutes & IV & Kidney, liver & 28 \\
7 & GSW & 2.77 & 15 minutes & III & Colon, kidney, small bowel & 41 \\
8 & Blunt & 7.84 & 7 hours & IV & Pancreas & 20 \\
\hline
\end{tabular}

RTS = revised trauma score; $A T I=$ abdominal trauma index; GSW = gunshot wounds.

*pyloric exclusion performed at reoperation after 36 hours (missed injury).
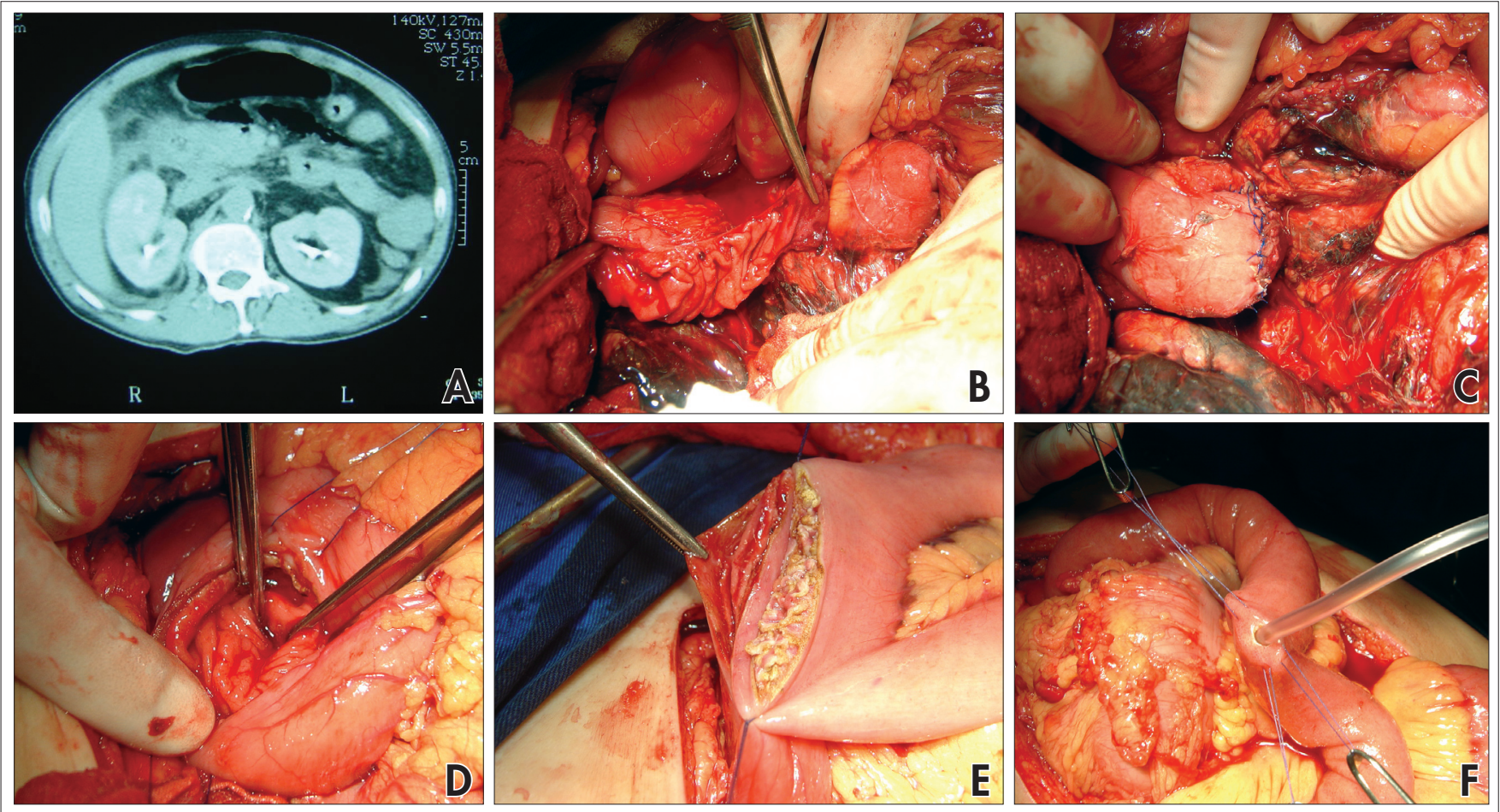

Figure 2. (A) Computed tomography showing air in retroperitoneum; (B) grade IV duodenal injury in third portion; (C) duodenal repair; (D) pylorus closed; (E) gastrojejunostomy; (F) feeding jejunostomy. 
patient with a large retroperitoneal hematoma, the posterior duodenal injury was missed in the first laparotomy and thus the procedure was carried out 36 hours post-injury. The most common injury site was the second portion of the duodenum, in five cases $(62.5 \%)$ and none of these involved the ampullary complex. The remaining three patients had injuries in the third portion. Four patients had grade III injuries and four had grade IV. Associated abdominal injuries were identified in all of the patients and are listed in Table 1. The mean ISS was $20.1 \pm 4.1$ and the mean ATI was $30 \pm 11.2$.

Feeding jejunostomy was performed in four patients (Figure 2). Six patients received a blood transfusion and the volume of packed red blood cells (PRBCs) was $1050 \pm 1100 \mathrm{ml}$. Postoperative complications were common (morbidity of $87.5 \%$; Table 2). Mortality was $50 \%$ (four patients) and, in three of these patients, it was related to pancreaticoduodenal injury. The overall mortality due to duodenal injuries out of the total pool of 93 patients was $28 \%$.

DISCUSSIDN

The management of duodenal injuries remains controversial, and this field lacks a consensus regarding what the optimal treatment should be. Approximately $70 \%$ to $85 \%$ of all duodenal injuries can be repaired safely by primary repair. ${ }^{2,3,13,14}$ Patients with severe duodenal injuries should be considered candidates for more complex duodenal repairs, such as duodenal diverticulization or pyloric exclusion. However, there is no clear definition regarding when these procedures should be indicated and which duodenal injuries should be considered severe. Certain factors may lead surgeons to consider an injury severe and order a complex procedure, including blunt trauma or bullet wounds, delay to repairs exceeding 24 hours, injury of the first or second portions of the duodenum, duodenal injuries of AAST-OIS grade $\geq$ III, associated injuries to the pancreas or common bile duct (or both) and compromised blood supply to the duodenum. . $^{1,2,4,13,15}$

The decision to use pyloric exclusion to repair a duodenal injury is multifactorial. This procedure appears to offer the best combination of limited surgery in cases of severely injured patients, with effective exclusion of the duodenum until after healing has occurred. Many authors have advocated the use of pyloric exclusion and have considered it to be the procedure of choice for patients with severe duodenal trauma. ${ }^{6,716-20}$ In our study,

Table 2. Postoperative complications and outcome

\begin{tabular}{lllcc}
\hline Patient & Complications & Reoperation & LOS & Survival \\
\hline 1 & Pancreatic fistula & No & 17 days & Yes \\
2 & Missed duodenal injury, sepsis, & Yes, repair and & 3 days & No \\
& MODS & pyloric exclusion & & \\
3 & Hepatic abscess, sepsis & No & 30 days & Yes \\
4 & Duodenal fistula, & Yes, drainage of abscess & 42 days & Yes \\
& abdominal abscess & No & 8 days & Yes \\
5 & None & Yes, treatment of & 14 days & No \\
6 & Pancreatitis, gastrojejunostomy & intra-abdominal infection & & \\
7 & fistula, sepsis, MODS & No hours & No \\
8 & Hemorrhagic shock, coagulopathy & No & 3 days & No \\
& ACS, pancreatitis, duodenal fistula, & Yes, decompressive & & \\
\hline
\end{tabular}

$L O S=$ length of stay; MODS = multiple organ dysfunction syndrome; $A C S$ = abdominal compartment syndrome.

pyloric exclusion was performed on $8.6 \%$ of all the patients with duodenal injury, and we believe that the procedure was a reasonable management method, except in one patient with hypovolemic shock.

Vaughan et al. ${ }^{6}$ used pyloric exclusion on 75 patients selected from a total of 175 (42.9\%) presenting with duodenal trauma, and had a mortality rate of $19 \%$ and a fistula formation rate of $5 \%$. In another study by Martin et al. ${ }^{16}$ including 313 patients with duodenal trauma, $128(41 \%)$ with severe duodenal injuries were treated with pyloric exclusion and the duodenal fistula rate was 5.5\%; two deaths due to fistulas occurred. Degiannis et al. ${ }^{18}$ studied pyloric exclusion for treating severe penetrating injuries of the duodenum, with a postoperative fistula rate of $43 \%(6 / 14)$ among patients who received only primary repair and $12 \%(2 / 17)$ among patients for whom pyloric exclusion was added to the surgical treatment. The authors concluded that grade III duodenal injuries due to gunshot wounds should always be treated with pyloric exclusion. ${ }^{18}$ Cogbill et al..$^{13}$ reported 164 duodenal injuries, among which 27 patients $(16.5 \%)$ were managed with pyloric exclusion. In their study, only two patients died secondary to duodenal complications (repair dehiscence and sepsis), thus suggesting that pyloric exclusion is a useful adjunct for more complex injuries.

Vagotomy is not usually part of this surgical procedure. ${ }^{6,16,18}$ Buck et al. ${ }^{17}$ described a study on 17 patients with severe pancreaticoduodenal injuries who underwent pyloric exclusion. Vagotomy was performed on eight of those patients. These authors reported high incidence of marginal ulcerations, and two patients without vagotomy presented with either perforations or bleeding and required reoperation. This complication rate was significantly higher than what had previously been reported, and the authors recommended that vagotomy should be added to pyloric exclusion at the time of the initial procedure. ${ }^{17}$ Ginzburg et al. ${ }^{19}$ performed pyloric exclusion without gastrojejunostomy on four patients, in order to avoid the extensive surgical repair required, so that they could focus on all the other associated injuries. They observed that spontaneous opening of the pylorus occurred and that the mean hospital stay was 29 days, thus concluding that gastrojejunostomy should not be used routinely on patients undergoing pyloric exclusion. ${ }^{19}$

In an experimental study on 30 rats subjected to pyloric exclusion with different occlusion suture materials and gastrojejunostomy with or without vagotomy, it was observed that nonabsorbable sutures maintained the pyloric closure for a longer duration (36.3 \pm 11.6 days) and that vagotomy reduced the gastric inflammation without influencing the time when the pylorus should be reopened. ${ }^{21}$ In another study from our laboratory, Pierro et al. ${ }^{12}$ compared the results from primary repair versus repair associated with pyloric exclusion and gastrojejunostomy to treat complex duodenal injuries in 24 dogs. They did not observe any differences in the incidence of duodenal stenosis, fistula formation, intraabdominal abscess or death between the two groups, but pyloric exclusion was a longer and more traumatic procedure, and it resulted in greater weight loss and increased incidence of vomiting among the animals. ${ }^{12}$

Primary repair, pyloric exclusion without vagotomy and gastrojejunostomy were used in all the patients in this study. Duodenal injuries have been associated with high morbidity, ranging from $38 \%$ to $100 \%$, with an average of $63.7 \% .{ }^{2}$ In the present study, only one patient $(12.5 \%)$ was discharged without complications after eight days. The other three surviving patients suffered from abdominal 
infections (one hepatic abscess in a patient with associated colonic and gastric injury and one case of intra-abdominal abscess) or fistula development (one pancreatic and another duodenal). In the literature, duodenal fistula rates range from $0 \%$ to $16.2 \%$, with an average incidence of $6.6 \% .^{2,3,13,15}$

In the current study, after the follow-up period of six months, the overall mortality rate for all duodenal injuries was $28 \%$ and $50 \%$ for the patients who underwent the pyloric exclusion procedure. We believe that this technique should not be used for patients with hypovolemic shock, for whom a faster procedure should be chosen. The patient with delayed surgical intervention because of an undetected injury developed peritonitis and ultimately died; this was directly attributable to the missed injury. Two other patients developed severe acute pancreatitis and anastomotic fistulas, related to duodenopancreatic trauma and sepsis. One 55-year-old patient treated recently (Figure 2) presented with a complex duodenal injury caused by blunt trauma and underwent surgery seven hours later. Twenty-four hours later, this patient presented multiple organ dysfunction syndrome in the abdominal compartment. During the decompressive laparotomy, we identified pancreatitis, and the patient developed a duodenal fistula and died on the third postoperative day. The overall mortality rate for duodenal injuries remains between $5.3 \%$ and $30 \%$, but injuries to the duodenum itself are responsible for a mortality rate of about $10 \%$. $^{1,2,4}$

A recent study by Seamon et al. ${ }^{7}$ examined patients with penetrating duodenal injuries of grade $\geq$ II and pancreaticoduodenal injuries, excluding patients who died within 48 hours due to massive associated injuries. Fifteen out of their 29 patients were treated without pyloric exclusion and 14 with exclusion, and the groups were similar with regard to sex, age, mechanism, hemodynamic stability, injury grade (a trend toward greater injury severity was noted in the pyloric exclusion group), ISS, associated abdominal injuries and mortality rates. None of these patients suffered a duodenal fistula. These authors reported a trend towards a higher overall complication rate in the pyloric exclusion group ( $71 \%$ versus $33 \%$ ), although this difference was not statistically significant. The same pattern was observed for the pancreatic fistula rate $(40 \%$ versus $0 \%)$ and the length of hospital stay (24.3 days versus 13.5 days), and the in-hospital mortality rates were similar in the two populations ( $21 \%$ versus $7 \%)$. The authors concluded that simple repair without pyloric exclusion was both adequate and safe for most penetrating duodenal injuries. ${ }^{7}$ Their report presented significant study limitations, as recognized by the authors. It was retrospective and the patients were not randomized, thus suggesting that pyloric exclusion could have been applied to higher-risk patients. The same could have occurred in the present study. In a letter to the editor commenting on the review by Seamon et al., Kashuk and Moore ${ }^{22}$ questioned their conclusion that pyloric exclusion should be abandoned, and pointed out that the review did not have sufficient scientific basis to justify abandoning this procedure.

CDNCLUSIONS

On the basis of our findings, although our study included a relatively small population, we believe that the general rule that "less is better" should be taken into consideration. Surgeons should be able to choose the best surgical procedure for managing patients with this challenging problem characterized by complex duodenal injuries. The role of pyloric exclusion requires further investigation in large, randomized and prospective trials, but we conclude that the indications for its use should be restricted during procedure selection and that patients usually seem to be safely treated with primary repair.
1. Weigelt JA. Duodenal injuries. Surg Clin North Am. 1990;70(3):529-39.

2. Asensio JA, Feliciano DV, Britt LD, Kerstein MD. Management of duodenal injuries. Curr Probl Surg. 1993;30(11):1023-93.

3. Fraga GP, Biazotto G, Villaça MP, Andreollo NA, Mantovani M. Trauma de duodeno: análise de fatores relacionados à morbimortalidade. [Duodenal trauma: factors related to morbimortality]. Rev Col Bras Cir. 2008;35(2):94-102.

4. Carrillo EH, Richardson JD, Miller FB. Evolution in the management of duodenal injuries. J Trauma. 1996;40(6):1037-45; discussion 1045-6.

5. Berg AA. Duodenal fistula: its treatment by gastrojejunostomy and pyloric occlusion. Ann Surg. 1907;45(5):721-9.

6. Vaughan GD 3rd, Frazier OH, Graham DY, Mattox KL, Petmecky FF, Jordan GL Jr. The use of pyloric exclusion in the management of severe duodenal injuries. Am J Surg. 1977;134(6):785-90.

7. Seamon MJ, Pieri PG, Fisher CA, et al. A ten-year retrospective review: does pyloric exclusion improve clinical outcome after penetrating duodenal and combined pancreaticoduodenal injuries? J Trauma. 2007;62(4):829-33.

8. Champion HR, Sacco WJ, Copes WS, Gann DS, Gennarelli TA, Flanagan ME. A revision of the Trauma Score. J Trauma. 1989;29(5):623-9.

9. Baker SP, O'Neill B, Haddon W Jr, Long WB. The injury severity score: a method for describing patients with multiple injuries and evaluating emergency care. J Trauma. 1974;14(3):18796.

10. Borlase BC, Moore EE, Moore FA. The abdominal trauma index--a critical reassessment and validation. J Trauma. 1990;30(11):1340-4.

11. Moore EE, Cogbill TH, Malangoni MA, et al. Organ injury scaling, II: Pancreas, duodenum, small bowel, colon, and rectum. J Trauma. 1990;30(11):1427-9.

12. Pierro AC, Mantovani M, Reis NS, Morandin RC, Fraga GP. Tratamento do trauma duodenal complexo: comparacāo entre sutura simples e sutura associada à exclusāo pilórica e gastrojejunostomia em cães. [Treatment of complex duodenal lesions: comparison between simple repair and repair associated to pyloric exclusion and gastrojejunostomy in dogs]. Acta Cir Bras. 2005;20(1):28-38.

13. Cogbill TH, Moore EE, Feliciano DV, et al. Conservative management of duodenal trauma: a multicenter perspective. J Trauma. 1990;30(12):1469-75.

14. Timaran $\mathrm{CH}$, Martinez O, Ospina JA. Prognostic factors and management of civilian penetrating duodenal trauma. J Trauma. 1999;47(2):330-5

15. Snyder WH 3rd, Weigelt JA, Watkins WL, Bietz DS. The surgical management of duodenal trauma. Precepts based on a review of 247 cases. Arch Surg. 1980;115(4):422-9.

16. Martin TD, Feliciano DV, Mattox KL, Jordan GL Jr. Severe duodenal injuries. Treatment with pyloric exclusion and gastrojejunostomy. Arch Surg. 1983;118(5):631-5.

17. Buck JR, Sorensen VJ, Fath JJ, Horst HM, Obeid FN. Severe pancreatico-duodenal injuries: the effectiveness of pyloric exclusion with vagotomy. Am Surg. 1992;58(9):557-60; discussion 561.

18. Degiannis E, Krawczykowski D, Velmahos GC, Levy RD, Souter
I, Saadia R. Pyloric exclusion in severe penetrating injuries of the duodenum. World J Surg. 1993;17(6):751-4.

19. Ginzburg E, Carrillo EH, Sosa JL, Hertz J, Nir I, Martin LC. Pyloric exclusion in the management of duodenal trauma: is concomitant gastrojejunostomy necessary? Am Surg. 1997;63(11):964-6.

20. Velmahos GC, Kamel E, Chan LS, et al. Complex repair for the management of duodenal injuries. Am Surg. 1999;65(10):972-5.

21. César JMS, Petroianu A, Gouvêa AP, Alvin DR. Reabertura do piloro gastroduodenal após sua cerclagem, em ratos. [Reopening of pylorus after its closure, in rats]. Rev Col Bras Cir. 2005;32(6):328-31.

22. Kashuk JL, Moore EE. Should pyloric exclusion for duodenal and pancreatico-duodenal injuries be abandoned? J Trauma. 2007;63(2):452-3.

Acknowledgement: Dr. Gustavo P. Fraga and Guilherme Biazzoto were recipients of fellowships from Fundação de Amparo à Pesquisa do Estado de São Paulo (Fapesp - number 06/57583-4), São Paulo, Brazil

Sources of funding: Fundação de Amparo à Pesquisa do Estado de São Paulo (Fapesp - number 06/57583-4)

Conflict of interest: None

Date of first submission: December 19, 2007

Last received: August 5, 2008

Accepted: November 3, 2008 
AUTHDR INFGRMATIDN

Gustavo Pereira Fraga, MD, PhD. Assistant professor, Division of Trauma Surgery, Department of Surgery, School of Medical Sciences, Universidade Estadual de Campinas (Unicamp), Campinas, São Paulo, Brazil; and Postdoctoral Fellow at University of California, San Diego (UCSD).

Guilherme Biazotto. Medical student, School of Medical Sciences, Universidade Estadual de Campinas (Unicamp), Campinas, São Paulo, Brazil.

José Benedito Bortoto, MD. Assistant surgeon, Division of Trauma Surgery, Department of Surgery, School of Medical Sciences, Universidade Estadual de Campinas (Unicamp), Campinas, São Paulo, Brazil.

Nelson Adami Andreollo, MD, PhD. Chairman and head of the Department of Surgery, School of Medical Sciences, Universidade Estadual de Campinas (Unicamp), Campinas, São Paulo, Brazil.

Mario Mantovani, MD, PhD. Chairman and head of Division of Trauma Surgery, Department of Surgery, School of Medical Sciences, Universidade Estadual de Campinas (Unicamp), Campinas, São Paulo, Brazil.

Address for correspondence:

Gustavo Pereira Fraga

Av. Cel. Silva Telles, 211 - Apto 3 - Cambuí

Campinas (SP) - Brasil - CEP 13024-000

Tel. $(+55$ 19) 3294-6348

Fax. (+55 19) 3243-8048

E-mail: fragagp@uol.com.br

Copyright () 2008, Associação Paulista de Medicina

\section{Exclusão pilórica no tratamento do trauma duodenal: série de casos}

RESUMD

CONTEXTO E OBJETIVOS: Há controvérsias a respeito do melhor tratamento cirúrgico para as lesões duodenais complexas. O objetivo deste estudo é relatar uma série de oito casos de reparo duodenal utilizando a exclusão pilórica e descrever a evolução dos pacientes com trauma duodenal complexo submetidos a este procedimento.

TIPO DE ESTUDO E LOCAL: Estudo transversal e descrição de série de casos em hospital universitário.

MÉTODOS: Foram coletadas e analisadas as informações de oito pacientes com trauma duodenal submetidos à exclusão pilórica em um período de 17,5 anos

RESULTADOS: Os mecanismos de trauma envolvidos foram ferimentos por projétil de arma de fogo em cinco pacientes e acidente automobilístico em três pacientes. O atraso do tratamento cirúrgico foi maior nos pacientes vítimas de trauma fechado, e em um paciente a lesão pelo projétil passou despercebida, sendo o procedimento cirúrgico realizado em nova laparotomia após 36 horas. As lesões duodenais encontradas foram grau III (50\%) ou grau IV (50\%), e a taxa de morbidade foi de $87,5 \%$. Quatro pacientes $(50 \%)$ morreram durante o período pós-operatório, de complicações como choque hipovolêmico (um caso), sepse (peritonite por ferimento não identificado), ou pancreatite associada à fístula da anastomose (dois casos).

CONCLUSÕES: A exclusão pilórica esteve associada à alta taxa de morbimortalidade. Esta técnica cirúrgica deve ser indicada em poucos casos de lesão complexa de duodeno e o cirurgião deve saber que, frente a uma lesão duodenal, a sutura primária pode ser o melhor tratamento.

PALAVRAS-CHAVE: Duodeno. Ferimentos e lesões. Suturas. Morbidade. Pancreatite. Gastroenterostomia. 